\title{
INTERFACIAL IONIC AND ELECTRONIC CONDUCTIVITY IN POLYMERS
}

\author{
Progress Report
}

for Period June 11988 - December 31, 1988

\author{
D. F. Shriver
}

Northwestern University

Evanston, IL 60208-3113

\begin{abstract}
NOTICE
This report was prepared as an account of work sponsored by the United States Government. Neither the United States nor the Department of Energy, nor any of their employees, nor any of their contractors, subcontractors, or their employees, makes any warranty, express or implied, or assumes any legal liability or responsibility for the accuracy, completeness, or usefulness of any information, apparatus, product or process disclosed or represents that its use would not infringe privately-owned rights.
\end{abstract}

June 1989

Prepared for

THE U. S. DEPARTMENT OF ENERGY

AGREEMENT NO. DE-FG02-85ER45220
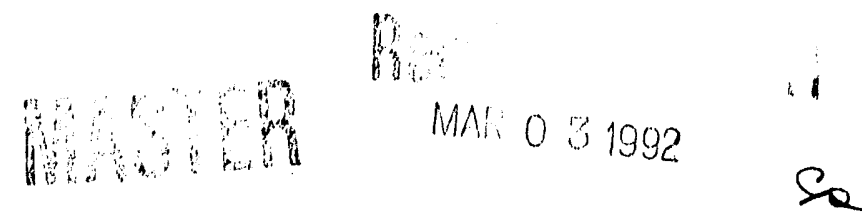


\begin{abstract}
New phosphazene-based single ion conductors were synthesized based on a polyphosphazene backbone and short-chain polyether sidechains, some of which are terminated with tetraalkylammonium groups. These materials are good anion conductors at room temperature. Related cation conductors were also prepared and characterized. Effects of interionic attractive interactions on the diffusion of a tracer were investicated theoretically. The results are relevant to ion pairing and trapping in polymer electrolytes.
\end{abstract}

\title{
Progress
}

Polyphosphazenes of the type $\left[\mathrm{NP}(\mathrm{OR})_{x}\left(\mathrm{OC}_{2} \mathrm{H}_{4} \mathrm{SO}_{3} \mathrm{Na}\right)_{2-\mathrm{x}}\right]_{n}$ were prepared and chemically characterized. Conductivities are on the order of $4 \times 10^{-7} \mathrm{ohm}^{-1} \mathrm{~cm}^{-1}$ at $30^{\circ} \mathrm{C}$ and $10^{-6} \mathrm{ohm}^{-1} \mathrm{~cm}^{-1}$ at $80^{\circ} \mathrm{C}$. These low conductivities are attributed to tight ion pairing between $\mathrm{Na}^{+}$and the sulfonate groups. Similar anion conductors were prepared eg. $\left[\mathrm{NP}(\mathrm{OMee})_{1.81}\left(\mathrm{OC}_{2} \mathrm{H}_{4} \mathrm{NMe}_{2} \mathrm{Et}^{+} \mathrm{I}^{*}\right)_{0.19}\right]_{\mathrm{n}}$. These materials have much higher conductivity (ca. $10^{-4} \mathrm{ohm}^{-1} \mathrm{~cm}^{-1}$ at $80^{\circ} \mathrm{C}$ ). These polyelectrolytes form an excellent testing ground for theories of ion transport in polymers because single ion diffusion coefficients are readily calculated from conductivity data.

The effects of interionic attractive interactions on the diffusion of a tracer ion in polyelectrolytes were studied using a one-dimensional hopping model. In this model the tracer cation is assumed to interact with anions placed at regular distances apart, but all inter-cation rerulsions are ignored. The effects of both anion density and temperature on the diffusion of the tracer were evaluated through simulation. The tracer is found no longer to undergo simple diffusion, but to display two different diffusion rates, one for local diffusion near an anion, and another slower rate for long-range diffusion. The local diffusion rate varies little with either stoichiometry or temperature, whereas the long-range diffusion is 
highly correlated to these variables. These behaviors are relevant to ion-pair trapping in polymer electrolytes.

\section{Doe Supported Publications 1988:}

"Synthesis, NMR, Characterization and Electrical Properties of Siloxane-Based Polymer Electrolytes", R. Spindler and D. F. Shriver, Macromolecules, 21, 648 (1988).

"Polymer Alkali-Metal Polyiodides with Variable Ionic and Electronic Conductivities", H. C. zur Loye, L. J. Lyons, L. C. Hardy, J. S. Tonge and D. F. Shriver, Mat. Res. Soc. Symp. Proc., 135, 325 (1988).

"Single-Ion Conducting Polymer Electrolytes", K. E. Doan, S. Ganapathiappan, K. Chem, M. A. Ratner and D. Fm. Shriver, Mat. Res. Soc. Symp. Proc., 135, 343 (1988).

"Generalized Dynamic-disorder Transport Rule with Application to the Study of Temporal Correlation Effects", S. D. Druger and M. A. Ratner, Phys. Rev., 12, 589 (1988).

"Ion Transport in Solvent-Free Polymers", M. A. Ratner and D. F. Shriver, Chem. Rev., $\underline{88}$ 109 (1988).

"Coulomb Trapping Effects in Polymer Solid Electrolytes: A Simulation Study of Stoichiometry Dependence", K. E. Doan, S. D. Druger, D. F. Shriver, M. A. Ratner and A. Nitzan, Mol. Cryst. Liq. Cryst., 160, 311 (1988).

"The Relationship between Hopping and Coherent Motion in Dynamically Disordered Systems", S. D. Druger and M. A. Ratner, Chem. Phys. Lett., 151, No. 4,5, 434 (1988).

"Dynamics of Ionic Motion in Polymeric Ionic Conductors", R. Granek, A. Nitzan, S. D. Druger and M. A. Ratner, Solid State Ionics, 28-30, 120 (1988).

"Fast Ion Conduction Some Theoretical Issues", M. A. Ratner and A. Nitzan, Solid State Ionics, 28-30, 3 (1988). 

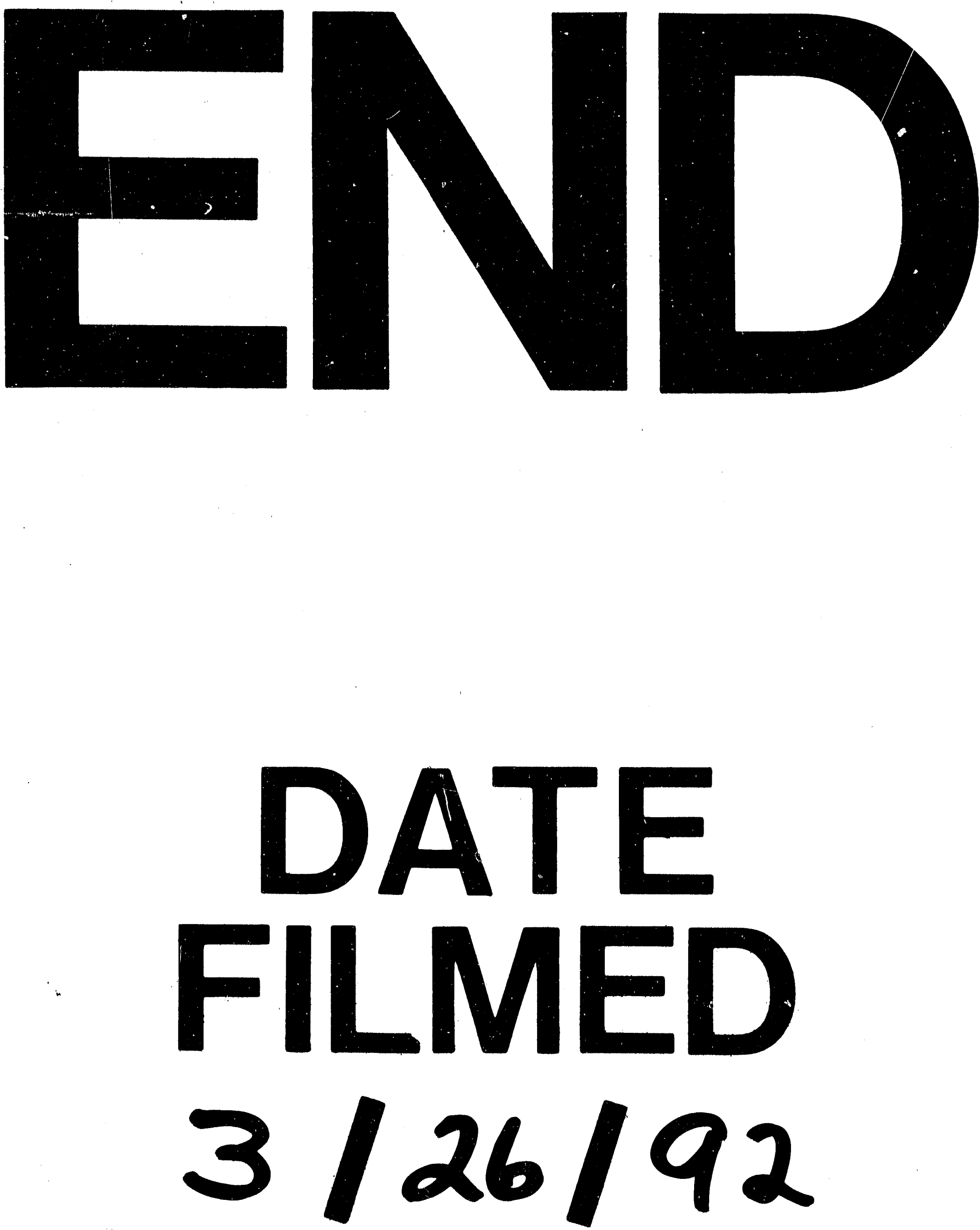
